\title{
Comparison of selected quality characteristics of domestic and Thailand multifloral honeys
}

\author{
BEATA MADRAS-MAJEWSKA, ELŻBIETA ROSIAK*, DANUTA JAWORSKA**, \\ KAROLINA KULESZA**, GRAŻYNA WASIAK-ZYS***, DARIUSZ TEPER ${ }^{* * * *}$ \\ Apiculture Division, Faculty of Animal Sciences, Warsaw University of Life Sciences in Warsaw, \\ Nowoursynowska 166, 02-787 Warszawa \\ *Department of Food Hygiene and Quality Management, Warsaw University of Life Sciences in Warsaw \\ **Department of Gastronomy, Warsaw University of Life Sciences in Warsaw

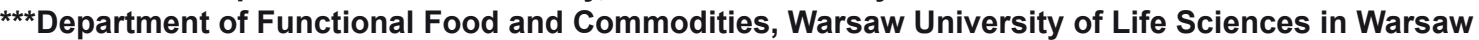

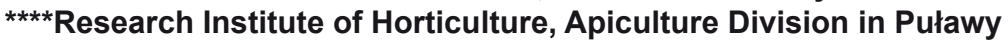

Madras-Majewska B., Rosiak E., Jaworska D., Kulesza K., Wasiak-Zys G., Teper D. Comparison of selected quality characteristics of domestic and Thailand multifloral honeys

Summary

The aim of this paper was to compare the microbiological and sensory quality of Polish and Thailand multifloral honeys. The honeys selected for testing were classified into the multifloral honey group on the basis of a pollen analysis. The microbiological analyses of multifloral honey samples confirmed a good microbiological quality of the honey samples tested. No presence of pathogenic bacteria of the species Salmonella has been demonstrated. The total number of aerobic mesophilic microorganisms and the number of mesophilic bacteria of the species Bacillus were less than the permissible microbiological limits for bee products. A significant excess of yeasts and moulds was found in one Thailand honey sample, which produced undesirable sensory factors as a result of honey fermentation. The tests performed revealed that lime and multifloral honeys were the varieties most preferred by consumers and that most consumers presented a neutral attitude towards imported honeys. A consumer sensory test showed differences in the quality of the honey samples tested. Three samples of domestic multifloral honeys and one sample of imported honey were assessed as the most attractive. Two Thailand honey samples were characterized by a significantly lower sensory quality than the other samples tested in the study. The method of sensory profiling applied in this study made it possible to be obtained precise information on the reasons for consumers' preferences identified during the hedonic test. The results for the most unattractive samples obtained by this method were confirmed by the results of microbiological and physicochemical analyses.

Keywords: honey, microbiological quality, sensory properties, consumers' preferences

Multifloral honey is the most common honey available in large quantities on the market, and therefore it is most often purchased and used by consumers. Because of the large number of producers offering multifloral honeys, consumers, in choosing a honey, should consider its health quality. The behaviour of modern consumers and their choices are associated with the wide variety of products and growing importance of information. Consumer testing consists in analysing the market behaviour of consumers and their attitude towards products being offered (3). Large groups of potential consumers take part in consumer questionnaire studies. Sensory testing is a source of useful information on perceived quality of products, including its most important aspect, i.e. the sensory attractiveness of products. Only fully accepted products are consumed by the consumers and bring about a pro-health effect. The honey market is principally segmented into honey for household consumption and honey for industrial use. An estimated $85 \%$ of all honey is destined for direct consumption (5).

Honey is characterized by a high concentration of sugars: fructose (average concentration 38.4\%), glucose (on average $30.3 \%$ ), sucrose (on average $1.3 \%$ ), other carbohydrates (about 12\%) and low protein concentration (on average $169 \mathrm{mg} / 100 \mathrm{~g}$ ) and mineral content (on average $0.169 \%)(22,45)$. According to Polish research, the overall sugar content in honey ranges from 64.0 to $88.6 \%$ (on average $79.1 \%$ ) (8) or from 76.0 to $80.5 \%$ (on average $78.9 \%$ (39). The honey nectar glucose content ranges from 27.3 to $37.4 \%$ (on average $31.0 \%$ ), and the fructose content from 29.1 
to $42.3 \%$ (on average $37.7 \%$ ) $(39,40)$. The protein content in honey is in the range of $500-10000 \mathrm{mg} / \mathrm{kg}$ (on average $2000 \mathrm{mg} / \mathrm{kg}$ ) (41), and mineral content ranges from 500 to $3500 \mathrm{mg} / \mathrm{kg}(8,25)$.

Moreover, the low content of water $(17.2 \%)$, low $\mathrm{pH}$ values (3.4-6.1), and the water activity within the range of 0.5 to 0.6 , as well as the presence of substances with antimicrobial activity (enzymes, phenolic compounds, flavonoids) result in honey being a difficult environment for the growth of most vegetative forms of human pathogenic microorganisms $(21,44,45)$. There are many publications describing the physicochemical and antioxidant properties of honeys $(11,14,23$, $35,49,53)$. On the other hand, studies on microbial contamination are mainly focused on the presence of Clostridium botulinum (1, 10, 24, 29, 30). Honey can be an environment for microorganisms such as osmophile yeast and moulds, whose numbers can achieve concentrations of several thousand of colony units per gram. These microorganisms, after exceeding the upper limit of water activity, are involved in the fermentation of honey, resulting in the formation of alcohol and carbon dioxide. An increasing level of fermentation leads to reduced sensory attractiveness of honey $(50,54)$. Spores of aerobic and anaerobic bacteria, especially Bacillus spp., and Clostridium spp., are responsible for microbial contamination of honey with their vegetative forms and toxins. The secondary sources of contamination (people, soil, animals, equipment) contribute to the presence of Gram-negative Enterobacteriaceae (E. coli, Salmonella, Shigella, Klebsiella, Proteus, Serratia, Cirtobacter, Edwardsiella), and Pseudomonas, as well as Gram-positive Staphylococcus and Enterococcus in honey. Honey is an excellent complement to many products in which microbes may find favourable conditions for growth and become the cause of microbiological contamination. In the assessment of the quality of honey, only physical and chemical criteria were taken into account (9). Microbiological and hygienic aspects were often ignored. The wide availability on the Polish market of foreign honeys of undocumented origin, and frequently low quality can pose a health risk. Hence, the aim of this study was to compare Polish and imported multifloral honeys in relation to their microbiological and sensory properties.

\section{Material and methods}

Research material consisted of 6 samples of honey (3 samples of Polish honey and 3 samples of honey from Thailand). Microbiological and physico-chemical analyses were carried out for 60 samples of different honeys (work in press). However, due to the difficulty of the consumer sensory test (80 consumers), studies were conducted only for six randomly selected samples, which provided a comprehensive examination. The set of a maximum of six samples made it possible to conduct a consumer study $(4,47)$.
All of the honeys from both countries were obtained from bee-keepers in 2013. The honeys were purchased at apiaries to avoid possible secondary contamination of the study material. Six honey samples were coded with letters A to F. The samples A, B and C were Thailand multifloral honeys, whereas the other samples denoted by letters D, E and $\mathrm{F}$ were Polish multifloral honeys. These were samples of mature honeys. The period from the time of collection at an apiary until the analysis did not exceed 6 months. The honeys were stored at a room temperature of $23 \pm 1^{\circ} \mathrm{C}$ in a darkened room.

Pollen analysis. A microscopic palynological analysis was carried out according to the methodology recommended by the International Commission for Bee Botany and International Honey Commission in order to determine the variety of honey and the compliance with Polish standards $(9,27,34)$.

\section{Methods of microbiological analysis}

Microbial counts. Ten grams of each sample was homogenized with $90 \mathrm{ml}$ of buffered peptone water (BPW) using a Somacher 400 instrument (IUL Instruments, Germany). Decimal dilutions were performed with BPW. The microbiological quality of honeys was tested by the reference plate method, and the analysis was performed on two parallel plates. The number of microorganisms was expressed as colony forming units per gram of honey (cfu/g).

The count of total mesophilic aerobic bacteria (TMAB) was determined by the ISO standard (19) with Plate Coumt Agar (PCA Biokar Diagnostics, Austria). The plates were incubated at $30^{\circ} \mathrm{C}$ for 3 days. The concentrations of mould and yeast were determined on Dichloran Rose Bengal Chloramphenicol Agar (DRBC Agar, Becton Dickinson and Co.) after incubation at $25^{\circ} \mathrm{C}$ for 5 days according to the ISO standard (18).

Bacterial detection. The honeys were tested for the presence of mesophilic spores of Bacillus spp., using Glucose Bromocresol Purple Agar (BCP Biokar Diagnostics), after incubation at $37^{\circ} \mathrm{C}$ for 5 days. Salmonella species were detected instrumentally with a BacTrac 4300 impedance camera (SyLab Geräte $\mathrm{GmbH}$, Austria). Analysis was performed with a BiMedia 201C Salmonella culture medium (modif. Rappaport-Vassiliadis media), and measurement cells were incubated at $40^{\circ} \mathrm{C}$ for $24 \mathrm{~h}$ (threshold $10 \%$ for the E-value).

Methods of physico-chemical analysis. The $\mathrm{pH}$ of honey was determined with a Lab 860 pHmeter (SI Analytics $\mathrm{GmbH}$, Schott Instruments, Germany). Honey samples of $10 \mathrm{~g}$ were diluted in $10 \mathrm{ml}$ of distilled water $(34,37)$.

The water activity was measured at $25^{\circ} \mathrm{C}\left( \pm 0,2^{\circ} \mathrm{C}\right)$ in a temperature-stable sampling environment with an AquaLab TE series 4 analyzer (Decagon Devices, Pullman, Washington, USA) calibrated with saturated salt solutions in the aw range of $0.40-0.70$. This device operates on the basis of electronic dew-point measurements. An AquaLab analyzer continues the analyses of water activity until the difference between three consecutive measurements is less than 0.0005 aw (54).

The water content in undiluted honeys was established by three or four measurements with a PAL-22S refractometer (Conbest Sp. z o. o., Poland) $(34,37)$. 


\section{Methods of sensory analysis}

The sensory testing consisted of three parts:

a) questionnaire study - as described below by the author of the paper,

b) consumer sensory test - according to (33),

c) laboratory sensory test - according to the ISO standard (17).

Questionnaire study and characteristics of respondents. The study consisted of completing a short questionnaire with questions by consumers. The questionnaire asked whether a given person consumed honey, how often, for what reasons, which were the preferred types and varietes of honey, what was the preferred origin of honey (domestic or imported), and what was the respondent's attitude towards imported honeys. A group of 200 persons (132 women and $68 \mathrm{men}$ ) participated in the questionnaire study. Around half of the participants in the study were residents of rural areas $(52 \%)$, and the rest lived in urban areas (48\%).

Consumer sensory test. A classic 9-point hedonic scale was used for the assessment of the acceptability of honey samples $(4,47)$. The group of 80 consumers who participated in sensory testing ( 51 women and 29 men) indicated that they consumed honey.

Laboratory sensory test. The method of quantitative descriptive analysis (QDA) was used to determine the analytical characteristics of honey samples according to the ISO standard (17). An evaluation panel of 10 persons determined the characteristics of the samples profile. The persons participating in the testing had appropriate methodological qualifications in accordance with the ISO standard (20) and considerable experience in the assessment of different products by the QDA method. The distinguishing qualitative attributes of odour, texture, flavour and overall quality were selected in accordance with the principles of the above-mentioned method. As a result of the selection, discussion and verification, 12 distinguishing qualitative attributes were determined. In addition, the overall sensory quality of each sample was defined. The intensity of each distinguishing attribute was indicated on an unstructured graphical scale (0-10 a.u. - arbitrary units).

Statistical analysis of results. The results were processed by means of an Excel sheet and presented as diagrams. They were analyzed statistically with the Statistica PL ver. 10.0 software (46). A single-variant analysis was used for the assessment of the significance of differences between the samples $(p<0.05)$. The interpretation of the results obtained by the QDA method was based on a principal components analysis. In addition, the coefficients of simple correlation were calculated between the overall honey quality and the assessed distinguishing features.

\section{Results and discussion}

Results of pollen analysis. The honeys analyzed had been declared by the beekeepers as varietals honeys. However, in the samples analyzed, there was no predominant pollen, so they were classified as multifloral (Table 1).

The results of physicochemical analysis. The $\mathrm{pH}$ value of the honeys ranged from 3.65 to 4.53 . These values were similar to those obtained by other authors $(2,6,14,26,31,42,43,48,51,52)$.

The water content is an important parameter in the assessment of the contamination of honey with fermentative microorganisms. The water content is related to external factors during the ripening and storing of honey. The allowed level is $20 \mathrm{~g}$ or less per $100 \mathrm{~g}$ of honey. The water content in Polish honeys conformed to the accepted standards except for sample E, in which it was $20.5 \%$. Among the imported honeys, samples B and C

Tab. 1. Results of pollen analysis of honey samples

\begin{tabular}{|c|c|}
\hline Samples & Description \\
\hline sample A & $\begin{array}{l}\text { Predominant pollen > } 45 \% \text { (not found). } \\
\text { Secondary pollen } 16-45 \% \text { (Chromolaena odorata 27.7\%; Coffea arabica 25.5\%; Helianthus annuus } 22.1 \% \text { ). } \\
\text { Important minor pollen 3-15\% (Litchi chinensis 12.5\%; Dimocarpus longan } 9.4 \% \text { ). } \\
\text { Minor pollen <3\% (Sesamum indicum } 2.8 \% \text { ). }\end{array}$ \\
\hline sample B & $\begin{array}{l}\text { Predominant pollen > 45\% (not found). } \\
\text { Secondary pollen } 16-45 \% \text { (Zea mays } 34.5 \% \text {; Litchi chinensis } 26.5 \% \text { ). } \\
\text { Important minor pollen 3-15\% (Sesamum indicum } 14.3 \% \text {; Mikania cordata 12.9\%; Ceiba pentandra } 11.8 \% \text { ). } \\
\text { Minor pollen < 3\% (not found). }\end{array}$ \\
\hline sample C & $\begin{array}{l}\text { Predominant pollen > 45\% (not found). } \\
\text { Secondary pollen } 16-45 \% \text { (Helianthus annuus } 26.3 \% \text {; Litchi chinensis } 25.9 \% \text {; Dimocarpus longan } 17.4 \% \text { ). } \\
\text { Important minor pollen 3-15\% (Coffea arabica 14.3\%; Chromolaena odorata 13.9\%). } \\
\text { Minor pollen < 3\% (Mikania cordata } 2.2 \% \text { ). }\end{array}$ \\
\hline sampleD & $\begin{array}{l}\text { Predominant pollen > } 45 \% \text { (not found). } \\
\text { Secondary pollen } 16-45 \% \text { (Trifolium 25.2\%; Trifolium pratense } 21.9 \% \text {; Brassica napus } 16.9 \% \text { ). } \\
\text { Important minor pollen 3-15\% (Melilotus 8.9\%; Centaurea cyanus 8.9\%; Anthriscus } 8.3 \% \text { ). } \\
\text { Minor pollen < 3\% (Fagopyrum 2.3\%; Prunus 1.7\%; Thymus 1.7\%; Vicia 1.3\%; Taraxacum 1.3\%; Tilia 1.0\%; Viola tricolor 0.7\%). }\end{array}$ \\
\hline sample E & $\begin{array}{l}\text { Predominant pollen > 45\% (not found). } \\
\text { Secondary pollen 16-45\% (Solidago 34.7\%; Rubus 21.1\%). } \\
\text { Important minor pollen 3-15\% (Salix 10,5\%; Prunus 8.9\%; Brassicaceae 8.4\%; Melilotus 4.7\%; Rosaceae } 4.2 \% \text { ). } \\
\text { Minor pollen < 3\% (Acer 2.7\%; Tilia 2.6\%; Fagopyrum 2.1\%). }\end{array}$ \\
\hline sample F & $\begin{array}{l}\text { Predominant pollen > 45\% (not found). } \\
\text { Secondary pollen 16-45\% (Salix 21.3\%; Trifolium 20.7\%). } \\
\text { Important minor pollen 3-15\% (Centaurea cyanus 12.8\%; Cirsium 12.2\%; Brassica napus 5.9\%; Anthriscus 4.3\%; Fagopyrum 4.3\%; Echium 4.3\%; } \\
\text { Frangula 3.2\%). } \\
\text { Minor pollen < 3\% (Lythrum 2.7\%; Robinia 2.7\%; Heracleum typ 2.7\%; Thymus typ 1.6\%; Tilia 1.6\%). }\end{array}$ \\
\hline
\end{tabular}


Tab. 2. Results of physicochemical analyses of honey samples

\begin{tabular}{|c|l|c|c|c|}
\hline Sample & $\begin{array}{c}\text { Country } \\
\text { of origin }\end{array}$ & Water activity & $\begin{array}{c}\text { Water content } \\
\mathrm{g} / 100 \mathrm{~g}\end{array}$ & $\mathrm{pH}$ \\
\hline A & Thailand & 0.57 & 17.8 & 4.16 \\
B & Thailand & 0.60 & 21.7 & 3.87 \\
C & Thailand & 0.59 & 20.5 & 3.65 \\
D & Poland & 0.53 & 18.8 & 4.12 \\
E & Poland & 0.54 & 20.5 & 4.53 \\
F & Poland & 0.54 & 18.3 & 3.92 \\
\hline
\end{tabular}

were characterized by the highest content of water: 21.7 and $20.5 \%$, respectively. Water activity is a parameter used for a better assessment of the possibility of microbial growth; for the osmophile yeast the treshhold value of water activity is $0.61 / 0.62$ (54). The Polish honeys were characterized by balanced values of water activity at a level of 0.53-0.54, whereas in the imported multifloral honeys aw values were higher, ranging between 0.57 and 0.60 (Tab. 2). Similar observations are reported by other authors. In five samples of Portuguese honey, water activity ranged from 0.47 to 0.56 (14). Water activity in Turkish honey (20 samples) was between 0.5 and 0.69 (49). The water activity of honey is determined by the molar concentration (moles/100 g water) of soluble substences. The fructose and glucose are $85-95 \%$ of carbohydrates in honey (14). Disacharides and other substances of relatively high molecular weight or those which are present in very small quantities make very little contribiution to the reduction of water activity in honey $(7,54)$. Water activity values for the Polish honeys were lower than those for the imported ones. It could have been caused by a higher concentration of monosacharides and a lower water concentration in the Polish honeys.

\section{Results of microbiological analysis}

Microbial counts. Microbiological examination showed contamination with aerobic mesophilic microflora at a level not exceeding $150 \mathrm{cfu}$ per gram of honey. In sample F, no aerobic microorganisms were found (Fig. 1). Similar results were obtained by other authors in Portugal, who reported aerobic microflora contamination not exceeding $10 \mathrm{cfu} / \mathrm{g}$ in 4 samples. In the $5^{\text {th }}$ sample a value of $200 \mathrm{cfu} / \mathrm{g}$ was found (14). In twenty samples of honey from Turkey (49), total

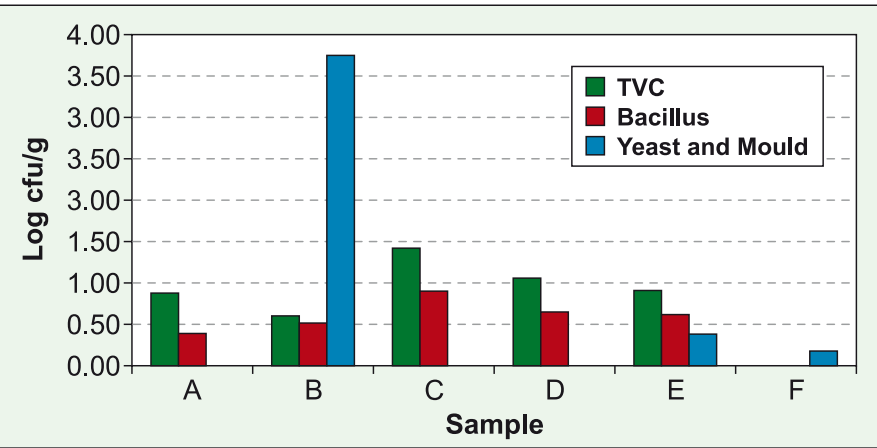

Fig. 1. Results of microbiological analyses of Thailand (samples A, B, C) and Polish (D, E, F) multifloral honeys mezophilic aerobic bacteria (TMAB) ranged between 2.00 and $3.96 \mathrm{log} \mathrm{cfu} / \mathrm{g}$. Some autors (30) reported contamination of 35 honey samples at a level of 0-83 $\mathrm{cfu} / \mathrm{g}$. Similar results were also obtained in a study of 38 Italian honey samples, in which contamination with oxygen microflora ranged from 1 to $318 \mathrm{cfu} / \mathrm{g}$ (44).

No yeasts or moulds were found in samples A, C and D. Contamination at a very low level, not exceeding 10 $\mathrm{cfu} / \mathrm{g}$, was found in samples E and F. On the other hand, the presence of yeasts and moulds at a level of $3.74 \mathrm{log}$ $\mathrm{cfu} / \mathrm{g}$ (Fig. 1) was found in sample B from Thailand. The highest water content, compared with the other samples, and an increased aw value was also determined in this sample. The relationship between the water content and the number of yeast-like mould cells that are able to initiate fermentation in 1 gram of honey is inversely proportional. If the water content is above $20 \%$, one mould cell may be sufficient to initiate fermentation. When yeasts-like moulds grow in thin honey, they break down monosaccharides, which initates fermentation. As a result of this process, ethyl alcohol and carbon dioxide are formed. This is followed by honey acidification due to the growth of bacteria that cause the formation of acetic acid and non-volatile acids with a characteristic aroma. The honey sample B was one of two samples negatively evaluated with respect to sensory attributes because of a tart, burning and sharp taste (Fig. 5). The crucial role of flavour and taste in honey perception is emphasized in many studies $(15,16,32)$.

Bacterial detection. The study did not reveal the presence of Salmonella spp in the samples. Similar results have been obtained by other authors $(14,21)$. Bacillus spp. have occurred in all honey samples at a level not exceeding $1 \mathrm{log} / \mathrm{g}$, except for sample $\mathrm{F}$, in which bacteria of this strain were not marked. In other studies (22), the presence of Bacillus spp. was demonstrated in $38.5 \%$ of samples.

There are currently no explicit microbiological criteria for honey. The directive of the Minister of Health (36-38) on maximal chemical and biological contamination permissible in food, which concerned bee preparations (royal jelly, pollen and propolis) and specified limits of microbiological contamination, is no longer in force. European regulations ignore or omit microbiological aspects in assessing the quality of honey (9). According to the guidelines contained in the above-mentioned superannuated directive, the no presence of bacteria of the species Salmonella. in $25 \mathrm{~g}$ of the product and no presence of coliforms in $0.1 \mathrm{~g}$ of the product is not permissible. The total number of aerobic mesophilic microorganisms in $1 \mathrm{~g}$ of the product cannot exceed $5 \times 10^{4}$, and the other permissible limits are $5 \times 10^{2}$ for yeasts and moulds, 100 for Staphylococcus aureus, and 100 for Bacillus cereus (38).

The honey samples analysed in this study contained less than $100 \mathrm{cfu} / \mathrm{g}$ of aerobic mesophilic microrganisms and less than $10 \mathrm{cfu} / \mathrm{g}$ of bacteria of Bacillus spp. Analyzed for the presence of yeasts and moulds, 5 honey samples contained less than $10 \mathrm{cfu} / \mathrm{g}$ of yeast- 
like mould. However, the permissible limit of $5 \times 10^{2}$ $\mathrm{cfu} / \mathrm{g}$, laid down by the directive of the Minister of Health (38), was exceeded in sample B (Fig. 1).

\section{Results of sensory test}

Results of questionnaire study. Only $7 \%$ of participats in the questionnaire study declared that they never consumed honey. Most respondents consumed honey a few times per month or less often $(57 \%)$. Their preferences as to types and varieties of honey are presented in Fig. 2. The participants in the study had a very clear preference for lime and multifloral honeys. They were less inclined to purchase acacia, honeydew and buckwheat honeys. In contrast, a study conducted in Romania (32) revealed that Romanian consumers preferred acacia honey the most. Polyfloral and lime honeys were also very positively perceived, as in the present study.

Asked about the reasons for consuming honey, respondents most frequently indicated its health qualities $(65.5 \%)$. Many respondents stated that they consumed it for pleasure. Few gave other reasons, including the use of honey as an addition to dishes, sauces, pickles and confectionery or as an alternative to sugar and consumption because of attractive taste and aroma. The consumers indicated that they used honey first and foremost to sweeten tea and less frequnetly consumed it with bread, used it as a medicine or added it to dishes and sauces. The use of honey as a cosmetic was the least common. Some of the respondents stated that they drank honey diluted in water with lemon juice. As buyers, most consumers $(78 \%)$ had a clear preference for Polish honeys. The other respondents $(22 \%)$ claimed that they paid no attention to the honey's country of origin. Asked about the attitude towards imported honeys, $62 \%$ of consumers answered that they had a neutral attitude, whereas 34\% described their attitude as negative.

The results obtained are similar to those from other studies $(28,32)$. In those studies consumers demonstrated a strong preference for local honey, due to the fact that they were generally sceptical about the quality of imported honey. They wished to buy a natural product or used it as therapeutic agent. Similar results, especially regarding preferences for local honey, were observed in another study (15).

An exploratory factor analysis concerning retail purchases of honey (13) revealed that the three factors with the strongest influence on consumers' choice were brand reputation, the origin of the honey, and value for money. Ethnicity was found to have a significant influence on the way in which honey was consumed in the household and on the importance of the three factors.

Some authors $(12,16)$ also concluded that taste, aroma, physical state, and colour had important influence on consumers' choice of honey. In addition to the above parameters, the perceived quality of honey was influenced by its source, brand name, and consumers' confidence in the producers.

Results of consumer sensory test. The mean results obtained with the use of a hedonic scale are presented

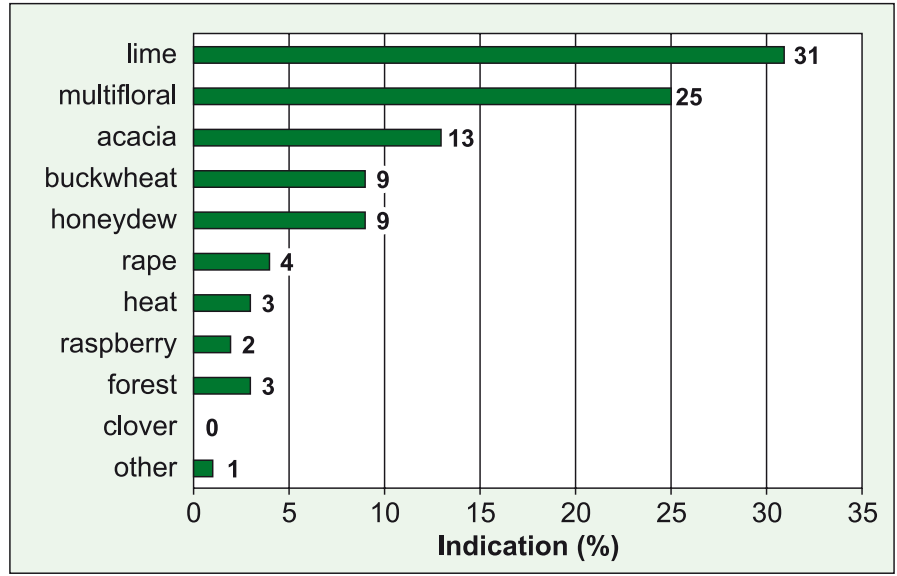

Fig. 2. Consumers' declared preferences with regard to types and varietes of honey $(n=187)$

Explanation: * Samples denoted by asterisks did not differ statistically $(\mathrm{p}<0.05)$

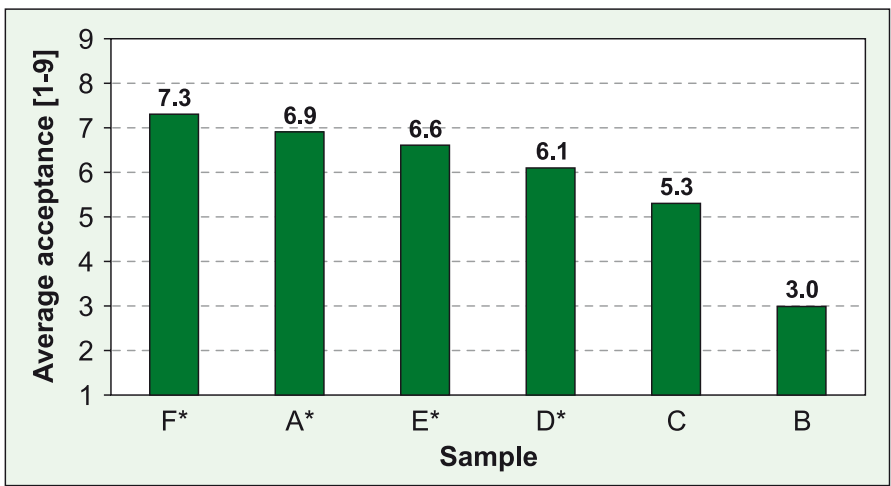

Fig. 3. Results of consumer sensory assessment (hedonic scale: $1-9 ; \mathbf{n}=80$ ) of Thailand (samples A, B, C) and Polish (D, E, F) multifloral honeys

in Fig. 3. Standard deviations were also calculated. The Polish multifloral honey in sample F was awarded the highest scores by consumers participating in the test, and the imported honey in sample B was assessed as the least desirable. There was no statistically significant difference (n.s.) between samples A, F, E and D. Samples $B$ and $C(p<0.05)$ received significantly lower scores. Only sample A of imported honey was among samples with high scores, which otherwise consisted exclusively of Polish honeys.

Results of sensory laboratory test. Averaged results obtained by quantitative descriptive analysis are presented in Fig. 4. In this analysis, samples B and C received significantly lower scores on overall quality, similar to the results obtained in the consumer study. The high intensity of negative distinguishing attributes, such as an odour described as "another", and the lower intensity of distinguishing attributes, such as a sweet or nectarous odour and flavour, resulted in a low quality of these samples. Each sample tested was characterized by its own individual sensory profile that defined its unique character. The intensity of colour, density, intensity of a pungent odour and intensity of "another" odour and flavour showed the widest diversity of distinguishing attributes. 


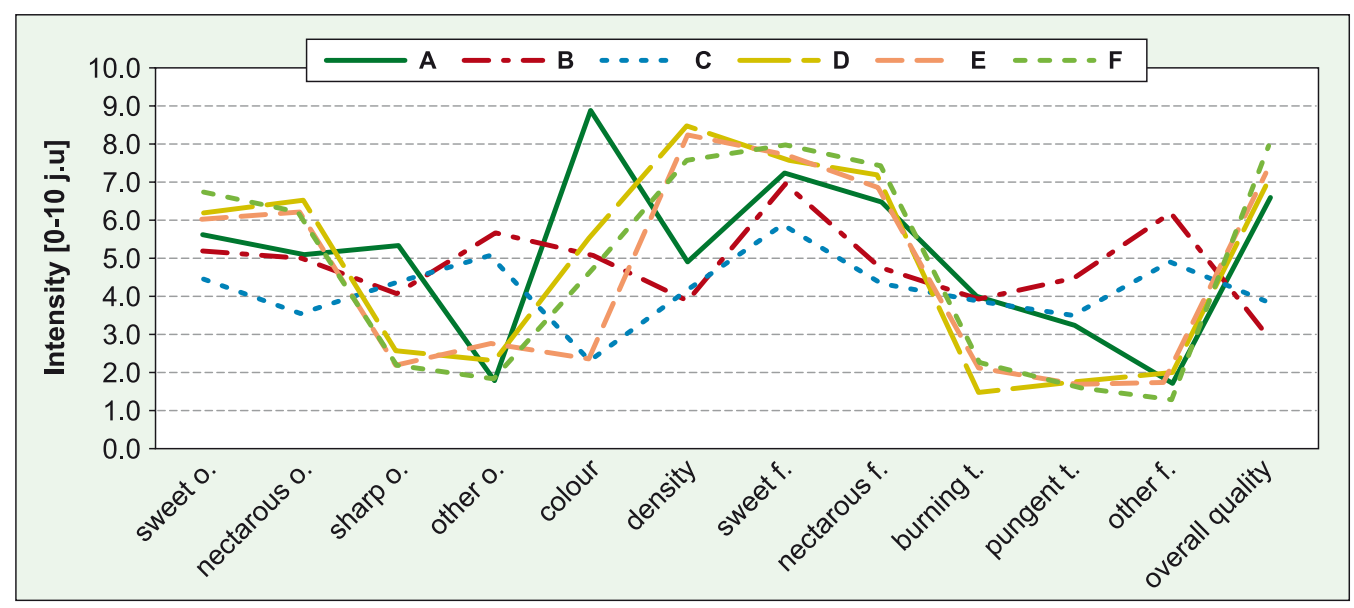

Fig. 4. Comparison of sensory quality of Thailand (A, B, C) and Polish (D, E, F) multifloral honey samples assessed by the quantitative descriptive analysis $(n=18)$

Explanations: o. - odour; f. - flavour; t. - taste

The analysis of variable components shows that the first two variables PC1 and PC2 contribute to $94 \%$ of total variability (Fig. 5). The results obtained represent a high similarity in the scores for samples E, F, D, as well as their high quality because of the proximity of these samples to the vector that describes the overall quality. The proximity of the scores for samples B and $\mathrm{C}$ to each other also indicates their high similarity in sensory profile, whereas their distant location in relation to the highest quality samples shows their low quality. Sample A is different from all other samples. It is located at the long vector that describes the colour, which indicates a considerable diversity of the samples in terms of colour and shows that the colour of sample A was significantly different from that of the others. EU consumers prefer light coloured honey with a mild taste, whereas honey from countries in the tropical zone is often dark and has a strong taste (5).

The analysis of the results obtained suggests that a nectarous flavour, sweet flavour, and high density

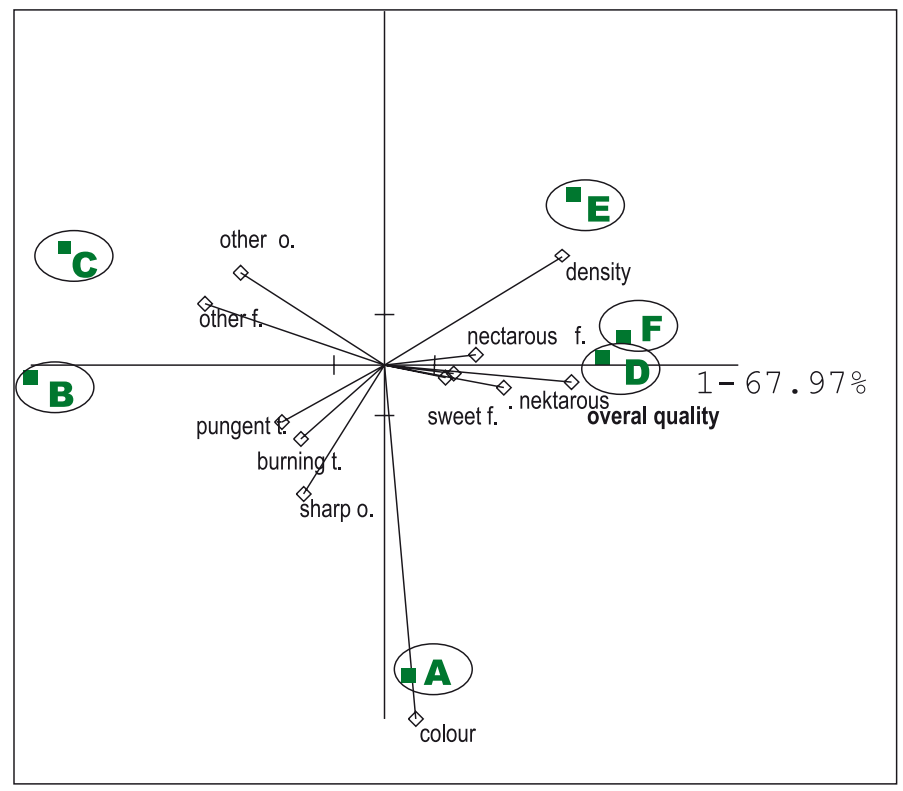

Fig. 5. Results obtained by the quantitative descriptive analysis with a principal component analysis of Thailand (samples A, B, C) and Polish (D, E, F) multifloral honeys had the greatest positive impact on the overall sensory quality $(\mathrm{r}=0.933$, $\mathrm{r}=0.769$ at $\mathrm{p}<0.005, \mathrm{r}=$ 0.785 , respectively). On the other hand, distinguishing attributes such as "another" flavour, a pungent taste and a burning taste had the greatest negative impact on the overall sensory quality $(\mathrm{r}=-0.981, \mathrm{r}=-0.915$ and $r=-0.716$, respectively). The results for the overall sensory quality obtained in the laboratory study were highly correlated with the results of the consumer sensory test $(r=0.894)$, which means that the above values of the distinguishing attributes were the most important in explaining the acceptance degree observed during the hedonic test.

The honeys with an intense nectarous and sweet flavour and aroma as well as a low level of pungent and burning sensation received the highest scores from the consumers and trained panelists.

The consumer sensory analyses demonstrated that samples B and C were the least attractive. A quantitative descriptive analysis of the sample B indicated a high inversely proportional correlation of the overall sensory quality with the following distinguishing attributes: "another" flavour, pungent taste and burning taste. The result of the sensory analysis was confirmed by a microbiological analysis of yeasts and moulds (3.74 $\log \mathrm{cfu} / \mathrm{g}$ ). The excess over the permissible yeast and mould limit of $2.70 \mathrm{log} \mathrm{cfu} / \mathrm{g}$ triggered fermentation in the sample that was also characterized by an increased water content $(21.7 \%)$. A breakdown of saccharides led, among others, to the formation of acids and ethanol, which resulted in unacceptable sensory attributes.

Among the 200 respondents, lime and multifloral honeys were the most preferred varieties. The results of the tests suggest that the consumers preferred products of local origin. Most consumers had a neutral attitude towards imported honeys.

The consumer sensory test showed a mixed quality of the honey samples; the local honey samples were characterized by a higher quality than the imported honey samples. The method of sensory profiling applied in the study provided precise information regarding the consumers' preferences identified in the hedonic test.

Microbiological analysis explained the causes of a low sensory evaluation of one of the imported honey samples. Substantial numbers of yeast and mould microorganisms had deteriorated its sensory attributes by fermentation. The low scores of some samples related to sensory unattractiveness could be explained by the results of microbiological and physicochemical analyses. 


\section{References}

1. Alsallami A. A., Kotłowski R.: Selection of primers for specific detection of Clostridium botulinum types B and E neurotoxin genes using PCR method. International Journal of Food Microbiology 2001, 69, 247-253.

2. Azeredo L. da C., Azeredo M. A. A., de Souza S. R., Dutra V., M., L.: Protein contents and physicochemical properties in honey samples of Apis mellifera of different floral origins. Food Chemistry 2003, 80, 249-254.

3. Barytko-Pikielna N., Kostyra E.: Współczesne trendy wyboru i akceptacji żywności. Przemysł Spożywczy 2004, 58, 12, 3-10, 31.

4. Barytko-Pikielna N., Matuszewska I.: Sensoryczne badania żywności. Wydawnictwo Naukowe Polskiego Towarzystwa Technologów Żywności, Kraków 2009.

5. Cbi Market Survey (2011): The honey and other bee products market in the EU. Http://www.cbi.eu/.

6. Celechovska O., Vorlova L.: Groups of honey - physicochemical properties and heavy metals. ACTA Vet BRNO 2001, 70, 91-95.

7. Chirife J., Zamora M. C., Motto A.: The correlation between water activity and \% moisture in honey: Fundamential aspects and application to Argentine honeys. Journal of Food Engeneering 2006, 72, 287-292.

8. Curyło J.: Chemia i technologia miodu i wosku, [w:] Hodowla pszczół. PWRiL, Warszawa 1983, s. 463-470.

9. EU, 2001. Council Directive 2001/110 relating to honey. Official Journal of the European Communities.

10. Fach P., Micheau P., Mazuet C., Perelle S., Popoff M.: Development of real-time PCR tests for detecting botolinum neurotoxins A, B, E, F producing Clostridium botulinum, Clostridium baratii and Clostridium butyricum. Journal of Applied Microbiology 2009, 107, 465-473.

11. Finola M. S., Lasagno M. C., Marioli J. M.: Microbiological and chemical characterization of honey from central Argentina. Food Chemistry 2007, 100, 1649-1653.

12. Gambaro A., Ares G., Gimenez A. N. A., Pahor S.: Preference mapping of colour of Uruguayan honeys. Journal of Sensory Studies 2007, 22, 507-519.

13. Ghorbani M., Khajehroshanaee N.: The study of qualitative factors influencing on honey consumers demand: Application of hedonic pricing model in Khorasan Razavi Province. J. of Applied Sciences 2009, 9, 1597-1600.

14. Gomes S., Dias L. G., Moreira L. L., Rodrigues P., Estevinho L.: Physicochemical, microbiological and antimicrobial properties of commercial honeys from Portugal. Food and Chemical Toxicology 2010, 48, 544-548.

15. Guau A., Akalakou C., Degrande A., Biloso A.: Determinants of consume preferences for honey in the Democratic Republic of Congo. J. of Food Products Marketing 2014, 20, 476-490.

16. Ismaiel S., Al-Kahtani S., Adgaba N., Al-Ghamdi A. A., Zulail A.: Factors that affect consumption patterns and market demands for honey in the Kingdom of Saudi Arabia. Food and Nutrition Sciences, 2014. 5, 1725-1737. http://dx.doi. org/10.4236/fns.2014.517186.

17. ISO 13299.2. (2003). Sensory analysis-methodology-general guidance for establishing a sensory profile.

18. ISO 21527-2. (2008). Microbiology of Food and Animal Feeding Stuffs Horizontal Method for the Enumeration of Yeasts and Moulds - Part 2: Colony Count Technique in Products with Water Activity Less Than Equal to 0.95. International Standard Organization. Switzerland

19. ISO 7218:2007/A1:2013. Microbiology of food and feedingstuffs. Genera requirements and guidance for microbial examinations. International Standard Organization. Switzerland.

20. ISO 8586-2. (1996). Sensory analysis. General guidance for the selection, training and monitoring of assessors part II - Experts.

21. Iurlina M. O., Friz R.: Characterization of microorganisms in Argentina honeys from different sources. Int. J. of Food Microbiology 2005, 105, 297-304.

22. Iurlina M. O., Saiz A., Fuselli S. R., Friz R.: Prevalence of Bacillus spp. in different food products collected in Argentina. LTW 2006, 39, 105-110.

23. Kahraman T., Buyukunal S. K., Vural A., Altunatmaz S. S.: Physico-chemical properties in honey from different regions of Turkey. Food Chemistry 2010 123, 41-44.

24. Küplülü Ö., Göncüoglu M., Özdemir H, Koluman A.: Incidence of Clostridium botulinum spores in honey in Turkey. Food Control 2006, 17, 222-224.

25. Lempka A.: Produkty spożywcze. Państwowe Wydawnictwo Ekonomiczne, Warszawa 1985, s. 223.

26. Litwińczuk Z. (red.): Towaroznawstwo surowców i produktów zwierzęcych z podstawami przetwórstwa. Powszechne Wydawnictwo Rolnicze i Leśne, Warszawa 2012, s. 471-483.

27. Louveaux J., Maurizio A., Vorwohl G.: Methods of Melissopalynology. Bee World 1978, 59, 139-157.

28. Murphy M., Cowan C., Henchion M., O’Reilly S.: Irish consumer preferences for honey: A conjoint approach. British Food J. 2000, 102, 585-598.
29. Nevas M., Hielm S., Lindstrom M., Horn H., Koivulehto K., Korkeala H.: High prevalence of Clostridium botulinum types A and B in honey samples detected by polymerase chain reaction. Int. J. of Food Microbiology 2002, 72, 45-52.

30. Nevas M., Lindstrom M., Hautamaki K., Puoskari S., Korkeala H.: Prevalence and diversity of Clostridium botulinum types A, B, E and F in honey produced in the Nordic countries. Int. J. of Food Microbiology 2005, 105, 145-151.

31. Persano Oddo L., Piro R.: Main European unifloral honeys: descriptive sheets Apidologie 2004, 35 (Suppl. 1), 38-81

32. Pocol C. B., Bolboac S. D.: Perceptions and trends related to the consumption of honey: A case study of North-West Romania. Int. J. of Consumer Studies 2013, 37, 642-649.

33. Peryam D. R., Pilgrim F. J.: Hedonic scale method of measuring food preferences. Food Technology 1957, 11, 9-14.

34. PN-88/A77626. Polska Norma. Miód pszczeli. Wydawnictwo Normalizacyjne.

35. Rall V. L. M., Bambo A. J., Lopes T. F., Carvalho L. R., Silva M. G.: Honey consumption in the state of Sao Paulo: a risk to human health? Anaerobe 2003 9, 299-303.

36. Rozporządzenie Ministra Rolnictwa i Rozwoju Wsi z dnia 18 lutego 2004 r zmieniające rozporządzenie w sprawie szczegółowych wymagań w zakresie jakości handlowej miodu. Dz. U. 2004 r. nr 40, poz. 370.

37. Rozporzadzenie Ministra Rolnictwa i Rozwoju Wsi z dnia 3 października 2003 r. w sprawie szczegółowych wymagań w zakresie jakości handlowej miodu. Dz. U. 2003 r. nr 181, poz. 1773 z późn. zm.

38. Rozporządzenie Ministra Zdrowia z dnia 13 stycznia 2003 r. w sprawie maksymalnych poziomów zanieczyszczeń chemicznych i biologicznych, które moga znajdować się w żywności, składnikach żywności, dozwolonych substancjach dodatkowych, substancjach pomagających w przetwarzaniu albo na powierzchni żywności. Dz. U. 2003 r. nr 37, poz. 326.

39. Rybak-Chmielewska H., Szczęsna T.: Determination of saccharides in multifloral honey by means of HPLC. J. of Apicultural Science 2003, 47, 93-101.

40. Rybak-Chmielewska H., Szczesna T.: Mono and oligosaccharides composition of some Polish unifloral honeys by means of gas chromatography. Pszczelnicze Zeszyty Naukowe 2000, 44, 325-333.

41. Rybak-Chmielewska H., Szczęsna T.: Skład chemiczny miodu pszczelego, [w:] Podstawowe zagadnienia jakości miodu. Wydawnictwo Instytutu Sadownictwa i Kwiaciarstwa. Oddział Pszczelnictwa, Puławy 1996, s. 10-15.

42. Rybak-Chmielewska H., Szczęsna T., Waś E., Jaśkiewicz K., Teper D.: Characteristics of Polish unifloral honeys. IV. Honeydew honey, mainly Abies alba L. J. of Apicultural Science 2013, 57, 51-59.

43. Semkiw P., Skowronek W., Skubida P.: Changes in water content of honey during ripening under controlled condition. J. of Apicultural Science 2008, 52, 57-63.

44. Sinacori M., Francesca N., Alfonzo A., Cruciata M., Sannino C., Settanni L., Moschetti $G$.: Cultivable microorganisms associated with honeys of differen geographical and botanical orgin. Food Microbiology 2014, 38, 284-294.

45. Snowdon J. A., Oliver D. O.: Microorganisms in honey. Int. J. of Food Microbiology 1996, 31, 1-26.

46. StatSoft, Inc. (2011). STATISTICA (data analysis software system), ver. 10 www.statsoft.com.

47. Stone H., Sidel J. L.: Sensory Evaluation Practices. Academic Press, San Diego 2004.

48. Szczęsna T., Rybak-Chmielewska H., Waś E., Kachaniuk K., Teper D.: Characteristics of Polish unifloral honey. I. Rape honey (Brassica napus L. var oleifera Metzger). J. of Apicultural Science 2011, 55, 111-119.

49. Tornuk F., Karaman S., Ozturk I., Toker O. S., Tastemus B., Sagdic O., Dogan M., Kayacier A.: Quality characterization of artisanal and retail Turkish blossom honeys: Determination of physicochemical, microbiological, bioactive properties and aroma profile. Industrial Crops and Products 2013, 46, 124-131.

50. Tysset C., Rousseau M.: Problem of microbes and hygiene of commercial honey. Rev. Mec Vet., Toulouse 1981, 132, 591-600.

51. Waś E., Rybak-Chmielewska H., Szczesna T., Kachaniuk K., Teper D.: Characteristics of Polish unifloral honeys. II. Lime honey (Tilia spp.). J. of Apicultural Science 2011a, 55, 121-128.

52. Waś E., Rybak-Chmielewska H., Szczęsna T., Kachaniuk K., Teper D.: Characteristics of Polish unifloral honeys. III. Heather honey (Calluna vulgaris L). J. of Apicultural Science, 2011b, 55, 129-136.

53. Wilczyńska A.: Jakość miodów w aspekcie czynników wpływających na ich właściwości przeciwutleniające. Rozprawa habilitacyjna, Akademia Morska w Gdyni 2012.

54. Zamora M. C., Chirife J., Roldan D.: On the nature of the relationship between water activity and \% moisture in honey. Food Control 2006, 17, 642-647.

Corresponding author: Beata Madras-Majewska, Assistant Professor, Apiculture Division, Warsaw University of Life Sciences in Warsaw, ul. Nowoursynowska 166, 02-787 Warszawa, Poland; e-mail: beata madras_majewska@sggw.pl 